\begin{abstract}
"Mircea cel Batran" Naval Academy Scientific Bulletin, Volume XIX - 2016 - Issue 1
Published by "Mircea cel Batran" Naval Academy Press, Constanta, Romania // The journal is indexed in:

PROQUEST / DOAJ / DRJI / JOURNAL INDEX / I2OR / SCIENCE LIBRARY INDEX / Google Scholar / Crossref /

Academic Keys / ROAD Open Access / OAJI / Academic Resources / Scientific Indexing Services / SCIPIO
\end{abstract}

\title{
MARITIME TRAFFIC IN THE ROMANIAN HARBOURS
}

\author{
Sergiu LUPU ${ }^{1}$ \\ Andrei POCORA ${ }^{2}$ \\ Romeo BOSNEAGU ${ }^{3}$ \\ Cosmin KATONA ${ }^{4}$ \\ ${ }^{1}$ Lecturer eng. PhD, "Mircea cel Batran" Naval Academy, Constanta, Romania sergiu.lupu@anmb.ro \\ 2 Assistant Professor eng. PhD student, "Mircea cel Batran" Naval Academy, Constanta, Romania \\ andrei.pocora@anmb.ro \\ 3 Associate Professor PhD, "Mircea cel Batran" Naval Academy, Constanta, Romania \\ romeo.bosneagu@anmb.ro \\ ${ }^{4}$ Asisstant Professor eng. PhD student, "Mircea cel Batran" Naval Academy, Constanta, Romania \\ cosmin.katona@anmb.ro
}

\begin{abstract}
This paper aims to address the issues of shipping in Constantza port in the light of new economic developments and its active role in achieving world trade. The paper is an analysis of the traffic of ships that entered/left/moved in recent years in Constantza. While ships, river vessels and companies are developing very quickly thanks to modern technology, administration and port services are marked by the inertia in terms of technological and organizational updating. Indeed, the creation and development of port facilities should take into account the transported cargo but, in order to have a beneficial success, a strategy to maintain a balance in the commercial market must be developed. Due to the free zone status, international trade has grown rapidly at the intersection of intermodal transport, the statistics showing that the volume of goods transported by sea increased almost 5 times in the last 40 years and for the next 20 years it requires a doubling.
\end{abstract}

Keywords: maritime transport, ship traffic, cargo, Constantza

\section{Introduction}

This article is a first preliminary study of the project in progress: System for detection, location, tracking and identification of risk factors against objectives in the area of seaside (SIROLC), from the national research programme, PN II 20142017, as the authors being part of this national project. The main objectives of this first study is to determine the needs for monitoring anthropogenic factors with the impact on the safety of the ship and the security of critical objectives located in the seaside area in the western part of the Black Sea: identification of cumulative risk and management risk.

A first approach to the threats and to the safety of navigation in Romanian coastline is the maritime traffic through the Romanian harbors by the organization, operation, threats, risks and proposals for cumulative risk management.

\section{PORT OF CONSTANTZA}

The port of Constantza, the largest port in the Black Sea and one of the largest in Europe, has a geographic location advantage being located on the routes of three main transport corridors: European Corridor IV (Dresden/Nuremberg Istanbul), Corridor IX (Helsinki - Alexadroupolis) and Corridor VII (the Danube River) which connects the North Sea to the Black Sea via the Rhine-Main-Danube corridors. The harbor is located on the west coast of the Black Sea, covers a total area of 3926 ha, 1313 ha land and 2613 ha water. It has two dams, the north one about $8.34 \mathrm{Km}$ and south one about $5.56 \mathrm{Km}$ in order to create optimal safety conditions for harbor activities. Also the harbor has an annual handling capacity of about 120 million tons and is served by 156 berths, of which 140 are operational, with a total length of $29.83 \mathrm{Km}$ and piers depths are between 7 to $19 \mathrm{~m}$.

Constantza harbor has a major role in the European network of intermodal transport, favorably

Constantza harbor has a major role in the European network of intermodal transport, favorably located at the intersection of trade routes linking landlocked country markets of Central and Eastern Europe with Transcaucas region, Central Asia and the Far East. Near the port are located two other ports, Midia harbor and Mangalia harbor, which are part of the Romanian harbor structure and under the coordination of Maritime Ports Administration Constantza.

This harbor is one of the main distribution centers serving Central and Eastern European region, giving a number of advantages among which the most important are:

- multipurpose harbor with modern facilities and sufficient water depths for berthing the 
"Mircea cel Batran" Naval Academy Scientific Bulletin, Volume XIX - 2016 - Issue 1

Published by "Mircea cel Batran" Naval Academy Press, Constanta, Romania /I The journal is indexed in:

PROQUEST / DOAJ / DRJI / JOURNAL INDEX / I2OR / SCIENCE LIBRARY INDEX / Google Scholar / Crossref /

Academic Keys / ROAD Open Access / OAJI / Academic Resources / Scientific Indexing Services / SCIPIO

largest vessels passing through the Suez canal;

- direct access to the countries of Central and Eastern Europe through Pan-European Corridor;

- distribution center for containers to the harbors of the Black Sea;

- good connections with all transport on the rail, road, inland waterways, air and pipeline;

- RO-RO terminals and ferryboat that ensures fast connections with the Black Sea and Mediterranean harbors;

- modern facilities for passenger ships;

- availability of areas for future development;

- free zone status which allows setting the framework necessary to facilitate trade and transit of goods to / from Central and Eastern Europe.

Constantza harbor is a seaport facilitating access for tanks with a capacity of 165000 dwt and 220000 dwt bulk carriers and also allowing any type of river ship. The connection between the Constantza harbor and Danube is made by the Danube-Black Sea Canal being one of the main advantages of this harbor. One of the advantages is the low costs and high volumes of transported goods, thus representing an efficient alternative to congested road and rail in Europe.

TO handle the increase in river traffic, the Maritime Ports Administration has achieved a barge terminal in the adjacent harbor, Agigea. This investment improves the navigation conditions and expands the facilities for ship to moor in the south of the harbor.

\section{RECOMMENDED COURSES AT THE ROMANIAN COASTLINE}

The maritime traffic in the Romanian area of responsibility at the Black Sea is organized according to Romanian legislation, which is aligned to the international IMO and IALA requirements. At the maritime traffic collaborate more specialized institutions like Romanian Naval Authority, Coast Guard, Maritime Hydrographic Institution etc.

Movement of vessels shall be in accordance with the rules published in the notice for mariners. All vessels with a tonnage greater than 300 GRT are bound to use the traffic routes known as traffic separation schemes in accordance with the Regulations for preventing collisions at sea COLREG.

\subsection{Recommended courses}

The recommended courses for navigations in the Black Sea are those that ensure maximum safety and possibilities to determine quickly and accurately the position of the vessel. They are systematically investigated in terms of depths and the existence of possible dangers to navigation. Recommended routes include information about the geographical positions of entry and exit point on the road, their true value and length. They are shown in Figures $1,2,3$ and 4 on an electronic map image.

a. Recommended course no. 1 through Mangalia harbor (Tab. 1 and Fig. 1)

Table 1.Recommended course no. 1
\begin{tabular}{|c|c|c|c|}
\hline $\begin{array}{c}\text { Wa } \\
y \\
\text { poin } \\
\mathrm{t}\end{array}$ & $\begin{array}{c}\text { Geographical } \\
\text { position }\end{array}$ & $\begin{array}{c}\text { Cour } \\
\text { se }\end{array}$ & $\begin{array}{c}\text { Distanc } \\
\mathrm{e} \\
{[\mathrm{Nm}]}\end{array}$ \\
\hline \multirow{2}{*}{1.} & Lat. $=43^{\circ} 47^{\prime} 59 \mathrm{~N}$ & \multirow{2}{*}{$090^{\circ}-$} & \\
\cline { 2 - 2 } 2 & Long. $=028^{\circ} 49^{\prime} 91 \mathrm{E}$ & \multirow{2}{*}{$270^{\circ}$} & 8,2 \\
\hline \multirow{2}{*}{2.} & Lat. $=43^{\circ} 47^{\prime} 59 \mathrm{~N}$ & \\
\cline { 2 - 2 } & Long. $=028^{\circ} 37^{\prime} 61 \mathrm{E}$ & & \\
\hline
\end{tabular}

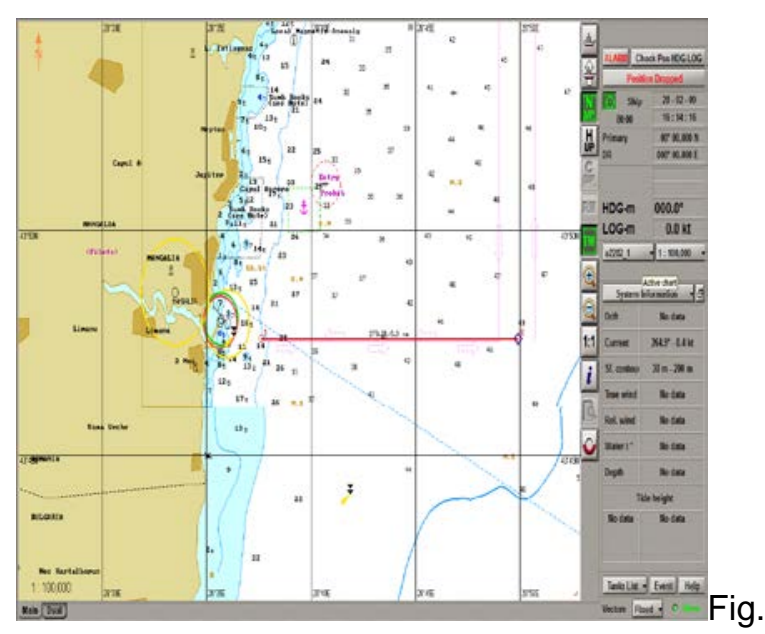

1.Recommended course no. 1

b. Recommended course no. 2 from the southern part of the maritime traffic scheme Mangalia and Midia(Tab. 2 and Fig. 2)

Table 2.Recommended course no. 2

\begin{tabular}{|c|c|c|c|}
\hline $\begin{array}{l}\text { Way } \\
\text { point }\end{array}$ & Geographical position & $\begin{array}{c}\text { Cours } \\
\mathrm{e}\end{array}$ & $\begin{array}{c}\text { Distance } \\
{[\mathrm{Nm}]}\end{array}$ \\
\hline \multirow{2}{*}{1.} & Lat. $=43^{\circ} 47^{\prime} 59 \mathrm{~N}$ & \multirow{6}{*}{$000^{\circ}$} & \multirow{4}{*}{11,28} \\
\hline & Long. $=028^{\circ} 50^{\prime} 86 \mathrm{E}$ & & \\
\hline \multirow{2}{*}{2.} & Lat. $=43^{\circ} 58^{\prime} 79 \mathrm{~N}$ & & \\
\hline & Long. $=028^{\circ} 50^{\prime} 86 \mathrm{E}$ & & \\
\hline \multirow{2}{*}{3.} & Lat. $=44^{\circ} 11^{\prime} 37 \mathrm{~N}$ & & \multirow{2}{*}{12,75} \\
\hline & Long. $=028^{\circ} 50^{\prime} 86 \mathrm{E}$ & & \\
\hline
\end{tabular}


"Mircea cel Batran" Naval Academy Scientific Bulletin, Volume XIX - 2016 - Issue 1

Published by "Mircea cel Batran" Naval Academy Press, Constanta, Romania // The journal is indexed in: PROQUEST / DOAJ / DRJI / JOURNAL INDEX / I2OR / SCIENCE LIBRARY INDEX / Google Scholar / Crossref / Academic Keys / ROAD Open Access / OAJI / Academic Resources / Scientific Indexing Services / SCIPIO

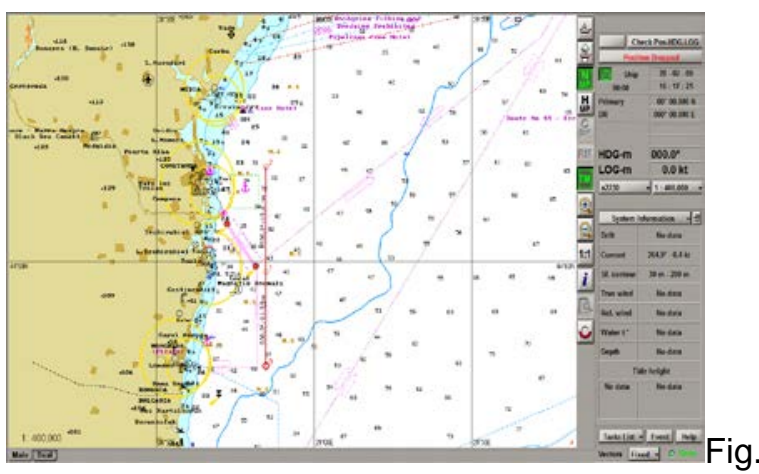

2 Recommended course no. 2

c. Recommended course no.3 from the traffic separation scheme (Tab. 3 and Fig. 3)

Table 3.Recommended course no. 3

\begin{tabular}{|c|c|c|c|}
\hline $\begin{array}{c}\text { Way } \\
\text { poin } \\
\mathrm{t}\end{array}$ & $\begin{array}{c}\text { Geographical } \\
\text { position }\end{array}$ & $\begin{array}{c}\text { Cour } \\
\text { se }\end{array}$ & $\begin{array}{c}\text { Distanc } \\
\mathrm{e} \\
{[\mathrm{Nm}]}\end{array}$ \\
\hline \multirow{2}{*}{1.} & Lat. $=43^{\circ} 58^{\prime} 39 \mathrm{~N}$ & & \\
\cline { 2 - 2 } & Long. $=028^{\circ} 48^{\prime} 96 \mathrm{E}$ & \multirow{2}{*}{$180^{\circ}$} & 10,85 \\
\hline \multirow{2}{*}{2.} & Lat. $=43^{\circ} 47^{\prime} 59 \mathrm{~N}$ & & \\
\cline { 2 - 2 } & Long. $=028^{\circ} 48^{\prime} 96 \mathrm{E}$ & & \\
\hline
\end{tabular}



3 Recommended course no. 3

d. Recommended course no. 4 Constantza Sulina

\begin{tabular}{|c|c|c|c|}
\hline $\begin{array}{c}\mathrm{Wa} \\
\mathrm{y} \\
\text { poin } \\
\mathrm{t}\end{array}$ & $\begin{array}{l}\text { Geographical } \\
\text { position }\end{array}$ & $\begin{array}{c}\text { Cours } \\
\mathrm{e}\end{array}$ & $\begin{array}{c}\text { Distanc } \\
e \\
{[\mathrm{Nm}]}\end{array}$ \\
\hline \multirow{2}{*}{1.} & Lat. $=43^{\circ} 59^{\prime} 54 \mathrm{~N}$ & \multirow{4}{*}{$\begin{array}{l}055^{\circ}- \\
235^{\circ}\end{array}$} & \multirow{4}{*}{47,5} \\
\hline & Long. $=028^{\circ} 48^{\prime} 80 \mathrm{E}$ & & \\
\hline \multirow{2}{*}{2.} & Lat. $=44^{\circ} 26^{\prime} 93 \mathrm{~N}$ & & \\
\hline & Long. $=029^{\circ} 43^{\prime} 20 \mathrm{E}$ & & \\
\hline 3. & Lat. $=44^{\circ} 36^{\prime} 49 \mathrm{~N}$ & $035^{\circ}-$ & 12 \\
\hline
\end{tabular}

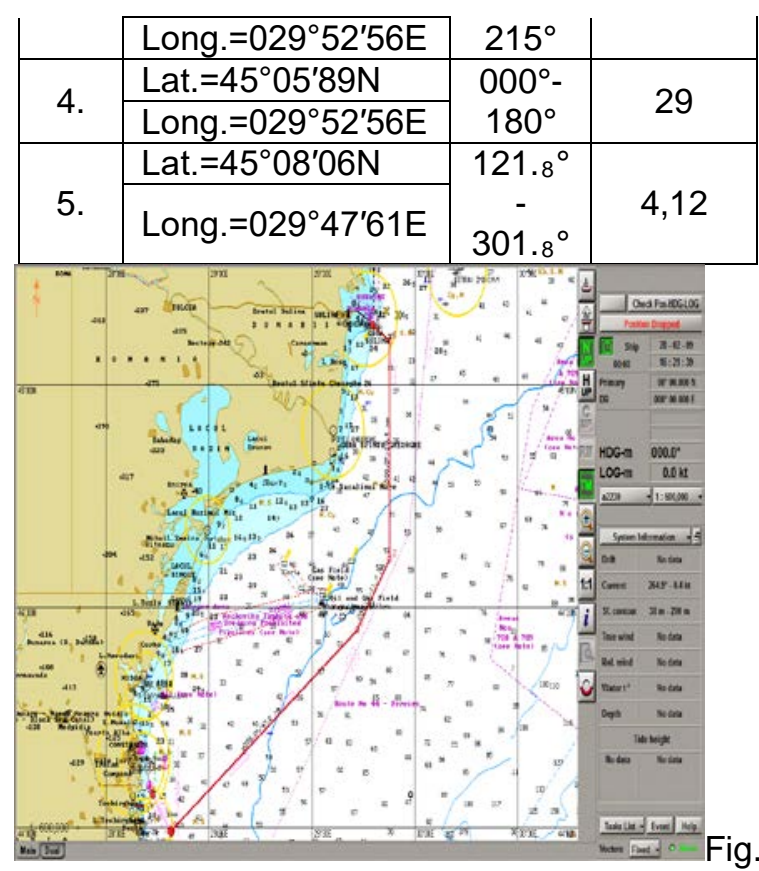

4 Recommended course no. 4

Ship traffic (input/output/removal) through seaports is monitored and coordinate by the Maritime Traffic Service (VTS).

This service provides supervision, coordination, monitoring and management of shipping traffic in order to:

-enhancing the safety of navigation;

- prevent potentially dangerous situations in traffic; - stream-lining and efficient traffic within the VTS area of Constantza.

\section{MARITIME TRAFFIC THROUGH CONSTANTZA HARBOUR}

From the documents from 2009-2014 and from the performed data analysis showed that maritime traffic recorded by VTS Constantza were as follows.

Table 5.Maritime traffic -2014

\begin{tabular}{|c|c|c|c|c|}
\hline MONTH & ENTRIES & EXITS & MOVEMENTS & TOTAL \\
\hline January & 318 & 295 & 50 & 663 \\
\hline February & 289 & 319 & 79 & 687 \\
\hline March & 324 & 343 & 64 & 731 \\
\hline April & 307 & 304 & 71 & 682 \\
\hline May & 348 & 358 & 72 & 778 \\
\hline June & 355 & 313 & 60 & 728 \\
\hline July & 371 & 381 & 113 & 865 \\
\hline August & 373 & 383 & 94 & 850 \\
\hline September & 413 & 379 & 112 & 904 \\
\hline Octomber & 403 & 415 & 124 & 942 \\
\hline November & 343 & 353 & 136 & 832 \\
\hline December & 322 & 338 & 115 & 775 \\
\hline $\begin{array}{c}\text { TOTAL } \\
2014\end{array}$ & 4166 & 4181 & 1090 & 9437 \\
\hline
\end{tabular}

(C) 2015. This work is licensed under the Creative Commons Attribution-Noncommercial-Share Alike 4.0 License. 
"Mircea cel Batran" Naval Academy Scientific Bulletin, Volume XIX - 2016 - Issue 1 Published by "Mircea cel Batran" Naval Academy Press, Constanta, Romania // The journal is indexed in: PROQUEST / DOAJ / DRJI / JOURNAL INDEX / I2OR / SCIENCE LIBRARY INDEX / Google Scholar / Crossref / Academic Keys / ROAD Open Access / OAJI / Academic Resources / Scientific Indexing Services / SCIPIO

Table 6.Maritime traffic between 2009-2014

\begin{tabular}{|c|c|c|c|c|}
\hline $\begin{array}{c}\text { TOTAL } \\
\text { YEAR }\end{array}$ & ENTRIES & EXITS & MOVEMENTS & TOTAL \\
\hline 2014 & 4166 & 4181 & 1090 & $\mathbf{9 4 3 7}$ \\
\hline 2013 & 4515 & 4639 & 935 & $\mathbf{1 0 0 8 9}$ \\
\hline 2012 & 4569 & 4696 & 880 & $\mathbf{1 0 1 4 5}$ \\
\hline 2011 & 4512 & 4619 & 817 & $\mathbf{9 9 4 8}$ \\
\hline 2010 & 4656 & 4772 & 962 & $\mathbf{1 0 3 9 0}$ \\
\hline 2009 & 4272 & 4574 & 749 & $\mathbf{9 5 9 5}$ \\
\hline
\end{tabular}

From the data traffic on the number of vessels monitored, coordinated and supervised by Constantza VTS area can be seen an increase in port activity in the period from July to October.

Regarding the type of ships transiting the port of Constantza in the period 2009 - 2014 data analysis shows the following situation (Table 7).

Table 7.Vessel traffic during $2009-2014$

\begin{tabular}{|l|c|c|c|c|c|c|}
\hline \multirow{2}{*}{$\begin{array}{l}\text { SHIPS } \\
\text { TYPE }\end{array}$} & \begin{tabular}{c}
$\mid c 0$ \\
\cline { 2 - 7 }
\end{tabular} & $\begin{array}{c}201 \\
0\end{array}$ & $\begin{array}{c}201 \\
1\end{array}$ & $\begin{array}{c}201 \\
2\end{array}$ & $\begin{array}{c}201 \\
3\end{array}$ & $\begin{array}{c}201 \\
4\end{array}$ \\
\hline Cargo & $\begin{array}{c}2.74 \\
8\end{array}$ & $\begin{array}{c}3.14 \\
5\end{array}$ & $\begin{array}{c}2.87 \\
9\end{array}$ & $\begin{array}{c}2.69 \\
2\end{array}$ & $\begin{array}{c}2.52 \\
5\end{array}$ & $\begin{array}{c}2.14 \\
6\end{array}$ \\
\hline $\begin{array}{l}\text { Passang } \\
\text { ers }\end{array}$ & 51 & 57 & 44 & 52 & 69 & 95 \\
\hline
\end{tabular}

\section{CONCLUSION}

The prosperity of every country depends heavily on foreign trade carried by sea.

Through this study we can forecast the shipping in the Romanian harbors and especially the port of Constantza, so they can develop strategies with directions of evolution and expansion of port facilities in the long term, taking into account the threats and risk factors at ship, safety and navigation and the critical objectives of the Romanian seaside.

In conditions projected by the growth of the national economy and the increasing importance of the European ports, in the Romanian harbors is expected that the vessel to rise and with this increasing it will bring the risks and threats to the safety of the vessel, navigation and different points of interests in the coastline

\section{BIBLIOGRAPHY}

[1] Beizadea, H., Mangamentul resurselor umane și formarea profesională în transporturile navale, 2002

[2] Song, D. W., Maritime logistics. Contemporary issues, 2015

[3] http://www.portofconstantza.com/apmc

[4] Transas Ltd. NAVI-SAILOR 3000

[5] Katona C., Alecu T., (2015),The cargo evolution trasnportion on romanian waterways Cernavodă-Agigea and Poarta Albă-Midia Năvodari, "Mircea cel Batran" Naval Academy Scientific Bulletin, Volume XVIII, Issue $1, \mathrm{p}$ 49-51. 